\title{
INFORMATION TECHNOLOGY ALLIED TO SUSTAINABILITY: GREEN IT APPLIED TO A CARRIER OF THE INDUSTRIAL POLE OF MANAUS
}

\section{${ }^{1}$ Adriel Vinícius Freitas dos Santos, ${ }^{1}$ Erick Wendell Nogueira Lobato, ${ }^{1}$ Bruno Pereira Gonçalves, ${ }^{2}$ Aline Mary Moreira de Melo, ${ }^{1}$ Rilmar Pereira Gomes, ${ }^{1}$ Jean Mark Lobo de Oliveira and 2David Barbosa de Alencar}

\author{
1Engineering Department of FAMETRO University Center, Amazon-Brazil \\ ${ }^{2}$ Institute of Technology and Education Galileo of Amazon (ITEGAM), Brazil
}

\section{ARTICLE INFO}

\section{Article History}

Received $11^{\text {th }}$ January, 2020

Received in revised form

$04^{\text {th }}$ February, 2020

Accepted $17^{\text {th }}$ March, 2020

Published online $30^{\text {th }}$ April, 2020

\section{Key Words:}

Sustainability, Green IT, Information Technology.

*Corresponding author:

David Barbosa de Alencar

\begin{abstract}
Faced with a new business scenario, organizations need to share the understanding between technological development and socio-environmental responsibility, since IT ally's sustainability and seeks community interaction with organizations, acting in an ecologically responsible manner. In this context, green IT helps to reduce the environmental problems caused by the disposal of technological equipment and incorrect use of technology. The methodology is a case study with bibliographic research, direct observation and quantitative research. The company studied has a high energy consumption due to the misuse of computer equipment and therefore, with the applicability of Green IT is possible to visualize and measure the benefits for the company, including not only the reduction of energy costs, but a sustainable education that favors the company and society as a whole. The results showed savings in monthly energy costs, while the reuse of paper reduces $50 \%$ of total paper consumption for document printing. So, it's noticeable that with the implementation of Green IT practices, even if implemented in a small business, if done in the long term, the benefits will be even greater and noticeable to the corporation and society.
\end{abstract}

Copyright (C) 2020, Adriel Vinicius Freitas dos Santos et al. This is an open access article distributed under the Creative Commons Attribution License, which permits unrestricted use, distribution, and reproduction in any medium, provided the original work is properly cited.

Citation: Adriel Vinícius Freitas dos Santos, Erick Wendell Nogueira Lobato, Bruno Pereira Gonçalves et al. 2020. "Information Technology Allied to Sustainability: Green IT Applied to a Carrier of the Industrial Pole of Manaus”, International Journal of Development Research, 10, (04), 35381-35386.

\section{INTRODUCTION}

One of the most relevant issues in organizational and governmental circles is sustainability. Since, when thinking about development, it is necessary to look more deeply into the issues that directly affect future generations. It is important that companies responsibly measure their attitudes towards the environment today so that they can broaden their life expectations in the global marketplace. According to the Global E-Waste Monitor study, conducted by the United Nations (UN), Brazil is the largest producer of electronic waste in Latin America, and the seventh largest in the world. Every year, the country produces 1,500 tons of electronic waste, and only $3 \%$ of this amount has adequate disposal (UN, 2018). Therefore, it is an environmental problem of extreme importance, since the chemical composition of the equipment is extremely toxic to the environment. In this way, there is an immediate need to think about information technology in a sustainable way, which meets the needs of companies, since the changes in hardware are constant and daily.
Through technology we have countless contents that we would never have the opportunity to know, either because of accessibility, distance or even lack of opportunity; we can connect to people who are physically distant, but working together with the same goal, at the same time (real-time); we can meet people, have fun, work, give opinions, protest. In this context, it seeks to emphasize that green IT values not only bringing sustainability to environmental parameters, but also, when applied within a company, it aims to reduce costs and adhere to more ecological practices to minimize the impact on nature. So that they educate not only their employees, but society itself, because it is a primordial practice for future generations. This study aims to analyze the applicability of Green Information Technology in a carrier of the Industrial Pole of Manaus, score the benefits of Green IT for the company, and finally, compare the cost-benefit for the company implementing Green IT. This carrier includes several transport areas, being them air, road, river and sea. Located in a region of Manaus Industrial District, tactically located to serve 
its customers. The company operates with a composition of 45 own vehicles and 150 outsourced, which have among them, carts, horses, trunk truck, munck, boards, among other heavy equipment for removal, lifting and cargo handling. Located in the strategic area of the Industrial Complex of Manaus (PIM), the company is active as a service provider in companies located in the Industrial Complex of Manaus (PIM), which is one of the most modern industrial and technological centers in all of Latin America, currently bringing together more than 600 state-of-the-art industries in the Electro-electronic, Two-wheel, Naval, Mechanical, Metallurgical and Thermoplastic segments, among others, which generate more than half a million direct and indirect jobs (SUFRAMA, 2017). The company has an administrative structure that is responsible for coordinating and monitoring all logistics activities, both in Manaus and the rest of Brazil.

Therefore, its Information Technology structure needs a rereading, since the administration employees interpose in their computer screens, monitoring software and logistics management of the company, from where they coordinate the drivers and helpers how to proceed with operations. In view of the carrier's work scenario, the following problems can be observed: technological equipment and/or hardware remain connected between 12 and 24 hours a day, printing uses a huge amount of paper daily, data is lost in computers when there is a power outage, and obsolete equipment is dumped in the filing room. Therefore, to reverse this picture, it was necessary to implement a series of Green IT practices in order to reduce the harm of Information Technology to the environment. Another preponderant factor is the interest in establishing itself in ISO 14001, which indicates the company's concern for environmental management, since ISO raises the organization's environmental policy, the nature of the activities developed by it, its products and services, the locations and conditions under which the system operates and the compliance with legal and statutory requirements of the market it operates. In other words, it certifies that the company is concerned with sustainable actions and protection of the environment and the community that is inserted.

Green Information Technology or Green it: The Technology of can be defined as the set of all activities, resources and solutions coming from the Informatics. In this same occasion, the Green IT concept has been used by the information technology sector to incorporate the concern with the environment and sustainability (GENESIS COMPUTER, 2018). Ecological issues, issues dealing with the preservation and rational use of natural and energy resources have become extremely important and are widely addressed in all sectors, being part of the daily lives of several companies, including the IT department. Corporations must invest in actions to meet the needs of a sustainable business and meet the Corporate Sustainability Indexes, a tool created to perform comparative analysis between companies on the aspects of corporate sustainability based on economic efficiency (WESTCON, 2020). In a broader context, Information Technology consists of hardware, software and people involved in obtaining, processing, storing, communicating and making information available. IT has been considered one of the most relevant components of the business environment, providing great opportunities for organizations that succeed in taking advantage of the benefits offered by this use (ALBERTIN; ALBERTIN, 2012). Hardware resources include devices such as computers, peripherals, server machines, network communication infrastructure, among others. On the other hand, resources coming from software include the set of programs aimed at operating systems, applications and utilities, security and database systems, and information system development platforms, among others (SOUZA, 2013). Within this scenario, there are numerous technological tools that emerge as sustainable IT options: Cloud Computing, Mobility, remote automated systems, technology reuse or even hardware retrofitting. This represents the changes in the market, both at the corporate and social levels. They are demonstrations of some practices recommended by TI Verde, such as: energy savings, server virtualization, use of videoconferencing, paper savings and disposal and recycling of electronic equipment (PINTO; SAVOINE, 2011). The evolution of technology and its different forms of use, also result in the emergence of new practices of TI Verde, in order to minimize the impacts caused by the use of IT. Energy is an indispensable input for society and in people's lives, given that it is necessary to enjoy its benefits rationally, avoiding waste. It is coherent to state that technological advances are exactly associated with the growth of humanity itself, one of these perspectives can be shown when evaluating the function performed by electricity in people's daily lives. Electric energy is now everywhere on the planet, in the homes of millions of people, it can be pointed out as one of the great revolutions of humanity since it has become one of the most relevant tools for the social and economic development of the modern world, consequently contemporary society (LUNARDI et al., 2014).

ISO 14001 Certification: ISO 14001 is internationally recognized as a standard that defines the achievements to establish an Environmental Management System (EMS). This standard aims to balance the maintenance of profitability and the reduction of environmental impact with committed organizations;thus, it is possible to achieve both objectives (BSI AMERICA, 2011). The ISO 14001 certificate is required by several countries for goods to be imported. In Brazil, ISO 14001 has strengthened the concept of sustainability BSI America (2011) further notes that the certificate is valid for three years, and should receive a further certification audit after that period. And even on time, the company receives annual audits in order to verify whether the certified system has undergone improvements and corrections. If the auditor finds irregularities and non-compliance, the seal may be cancelled.

A company that has an ISO 14001 certification is already benefited by several aspects, such as the reduction of accident risks, such as legal sanctions; increase in the quality of the products and services provided; reduction in the consumption of raw materials, water and energy; among other benefits.

Energy Economics: The use of energy in the world usually goes through a series of transformation stages from the primary stage to the energy services that matter, such as light, movement or heat, equipment uses, etc. Therefore, it is known that technology today demands a high energy capitation, since most, if not all, technological devices need battery and energy source. Thus, when thinking about the necessary use of technology, circumstantially one thinks of unrestrained and disordered energy consumption. At this time, Green IT also comes to the fore, with the aim of raising awareness and rationalizing the way in which the uses of technologies demand energy consumption, often unnecessary and excessive. Generating economic expenses for companies and also to harm the sustainable development of future generations. Therefore, the use of initiatives that seek to achieve this improvement in 
consumption brings some benefits, such as reducing gas emissions and impacts on the environment, improving processes and equipment and contributing to awareness against waste.

\section{MATERIALS AND METHODS}

The research methodology used in this work is the case study, descriptive research and bibliography. The approaches explained in the work will be of qualitative and quantitative nature. Quantitative researches aim at collecting concrete facts: numbers, in which they are structured and statistical. The material used in the quantitative data collection was the Google Forms tool, which is a free service to create online forms. The tool is suitable for those who need to request feedback or know about people's opinions in general. In the publicly available questionnaire, it was possible to measure the level of knowledge that 93 people have about the subject Green IT. The participating audience is diverse. The information relevant to energy consumption and use of equipment was passed on by those responsible in the administrative sector, and provided access to all equipment, including obsolete equipment.

\section{RESULTS AND SISCUSSION}

The demand for information for its customers requires the use of no breaks equipment, computers servers, notebooks, All Ones, printers and drives. For data analysis are presented in table 1 . According to a survey carried out at the location where the administration of the carrier works, it was observed that the location has a technological structure of: Since this is a company whose follow-up requires immediate information, the technological devices remain connected during periods that include both the presence of employees and their absence. Consuming an unnecessary energy demand for the company.

Other factors, which demand an excessive expenditure is the use of printing by the operational team, which often discards the papers without even being used. Thus, generating an increase in the amount of waste.

This way, due to the unregulated use of the technological equipment in the carrier, it will be necessary to apply configurations in the employees' computers when they have not made use of the machine, configure the printers to print documents on the front and back of the sheet, apply programs so that it will be possible for the technical responsible to access the computers remotely, make possible a hardware structure that meets the company's demand and that the equipment does not become obsolete quickly. Even being small, the company has a high energy consumption due to the misuse of computer materials and waste of electrical energy.

The company has a standard of service in which it needs to be constantly connected to e-mails, phones, trackers and price list. Soon, the service starts at $07 \mathrm{~h}$ and ends at $17 \mathrm{~h}$. However, some machines and displays stay on 24 hours so that in emergency cases you can immediately view the vehicles.

\section{The application of green IT started through the following steps:}

- All Ones and notebooks were programmed to go into rest mode after 5 minutes without activity;
- Discarded papers that have one side will be reused for draft and reprint;

- The servers have become machines mounted for the reception and warehouse;

- The displays should be turned off, thus keeping only the Jabursat monitoring equipment on;

- The printers are in standby mode;

- The notebooks that previously were directly in the outlet, charge and are used until the end of the battery so that it does not consume unnecessary energy.

According to Graph 1, energy costs with unregulated consumption of technological equipment in the months of October to December 2019, months prior to the application of green IT. The changes occurred in the period from December 2019 to January 2020, thus, one can notice the significant decrease in the energy cost of the subsequent months, according to Graph 2. Therefore, it is possible to analyze the difference in the months of January, February and March 2020. In this way it was observed that the average energy cost in the previous scenario resulted in a difference of $\mathrm{R} \$ 1.289,45$. That is, the difference is significant when applied with a strategic and sustainable change in information technology. It was observed that green IT can represent energy savings by promoting resource management. In addition, it is possible and remarkable to reduce waste and increase efficiency of all processes and equipment related to the technology department. As for the disorderly consumption of paper for printing, the following information was obtained, see table 3 .

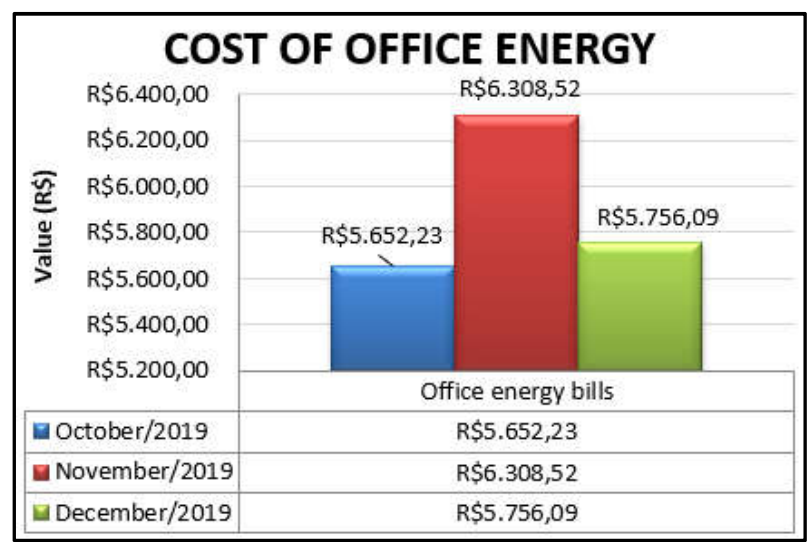

Graph 1 - Energy costs before applying Green IT Source: Authors, 2020.

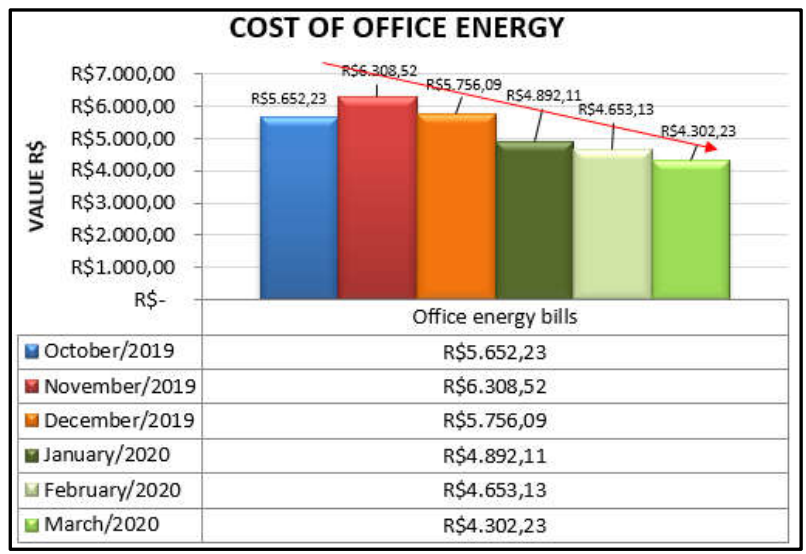

Graph 2 - Energy costs before and after the application of Green IT Source: Elaborated by the Authors. 
Table 1 - Equipment arranged in the company

\begin{tabular}{clll}
\hline Quant & Description & Mark & Time of use \\
\hline 10 & All-One Computer & Positive & 8 to $12 \mathrm{~h}$ \\
5 & Notebook & Lenovo & $12 \mathrm{~h}$ \\
1 & Multifunctional Printer & Epson & $24 \mathrm{~h}$ \\
3 & Multifunctional Printer & Samsung & $24 \mathrm{~h}$ \\
1 & Printers & Brother & $24 \mathrm{~h}$ \\
1 & Nobreak & APC & $24 \mathrm{~h}$ \\
2 & CPU Server & Acer & $24 \mathrm{~h}$ \\
1 & Card printer & Zebra & $8 \mathrm{~h}$ \\
5 & 55' Televisions & Samsung & $24 \mathrm{~h}$ \\
3 & Displays & Acer & $24 \mathrm{~h}$ \\
\hline
\end{tabular}

Table 2. Cost Comparison - Before and After Green IT Application

\begin{tabular}{lcc}
\hline \multicolumn{4}{l}{ AVERAGE ENERGY COST } \\
\hline $\begin{array}{l}\text { Before } \\
\text { (Oct/Nov/Dec) }\end{array}$ & After (Jan/Feb/Mar) & Difference \\
R\$ 5.905,61 & R \$ 4.616,16 & $-\mathrm{R} \$ 1.289,45$ \\
\hline Source: Authors, 2020. &
\end{tabular}

Table 3. Paper consumption (before green IT)

\begin{tabular}{lll}
\hline \multicolumn{2}{l}{ A4 PAPER CONSUMPTION FOR PRINTING } \\
\hline Printers & Quantity of reams of paper & Consumption of reams \\
& per equipment (week) & of paper a4 (monthly) \\
4 & 2 & 32 \\
\hline
\end{tabular}

Source: Authors, 2020.

Table 4. Paper Consumption - Before and After Consumption Change

\begin{tabular}{|c|c|c|}
\hline \multicolumn{3}{|c|}{ PAPER CONSUMPTION COMPARISON FOR IMPRESSÃO } \\
\hline Consumption & Before & After \\
\hline $\begin{array}{l}\text { Monthly consumption } \\
\text { of reams }\end{array}$ & 32 units & 18 units \\
\hline Monthly Cost & $\mathrm{R} \$ 448,00$ & $\mathrm{R} \$ 252,00$ \\
\hline Annual cost & $\mathrm{R} \$ 5.376,00$ & $\mathrm{R} \$ 3.024,00$ \\
\hline
\end{tabular}

Source: Authors, 2020.

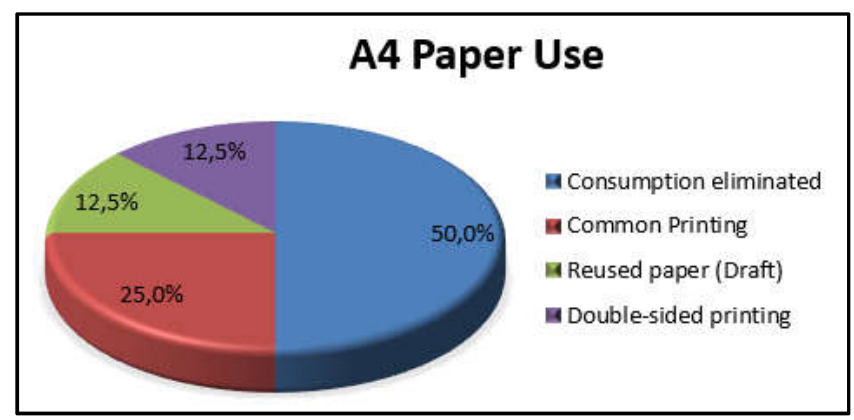

Graph 3. Consumption of 44 reams of paper after application of Green IT Source: Authors, 2020.

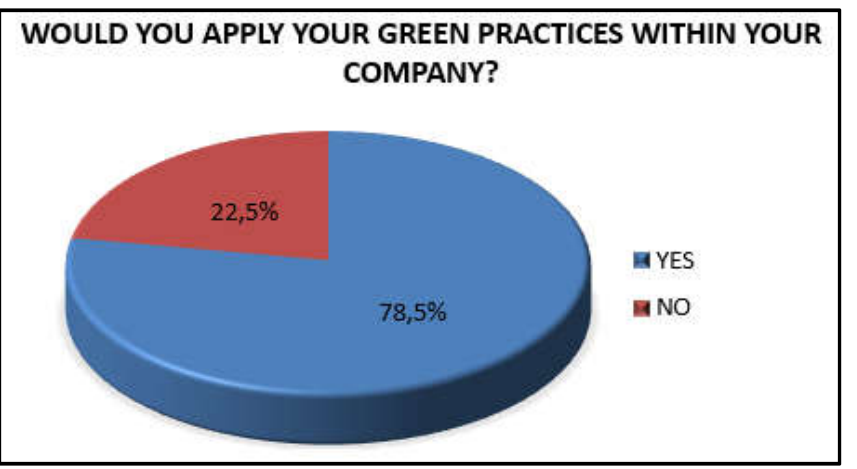

Graph 4. Questioning on the applicability of Green IT practice within firms Source: Authors, 2020.

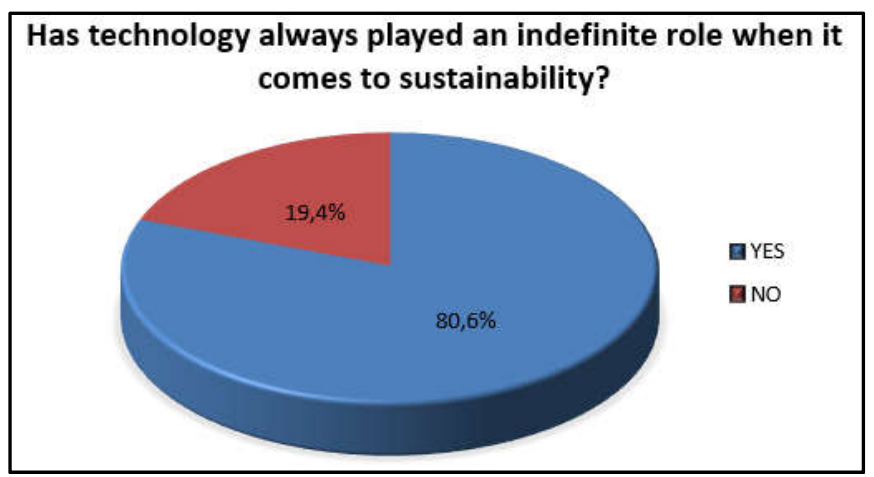

Graph 5. Has technology always played an undefined role when it comes to sustainability? Source: Authors, 2020.

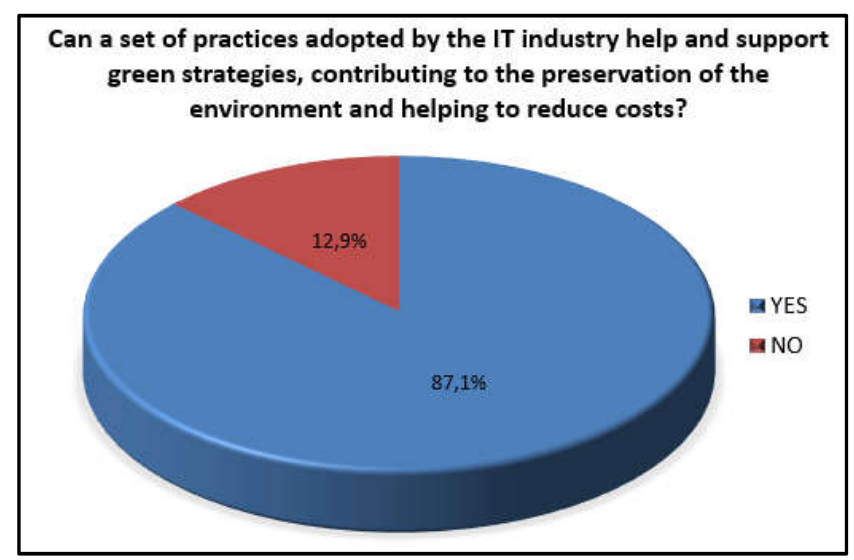

Graph 6. Can a set of practices adopted by the IT sector help and support green strategies, contributing to the preservation of the environment and helping to reduce costs? Source: Authors, 2020.

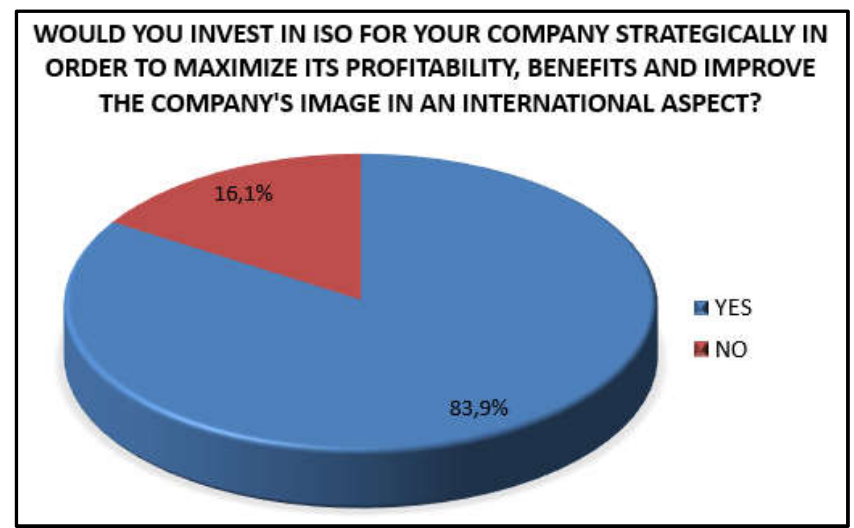

Graph 7. Would you invest in ISO for your company in a strategic way, in order to maximize its profitability, benefits and improve the company's image in an international aspect? Source: Authors, 2020.

Considering that the ream of paper costs around $\mathrm{R} \$ 14,00$, the expenses with the purchase of reams of paper are $\mathrm{R} \$ 448,00$ monthly. Applying the front and back printing configurations and reusing paper, possibly disposable for draft, the consumption scenario is changed in almost half of the previously used, according to table 4. Economically, the Transporter eliminates $50 \%$ of the paper consumption, that is, it reduces a cost of $\mathrm{R} \$ 3.024,00$ annually, at the same time that it reuses the material (paper) for other printings. According to graph 3, the consumption of reams of A4 paper was eliminated in $50 \%$, and the $50 \%$ of consumption used with the implementation of green IT becomes $25 \%$ of normal printing, $12,5 \%$ reuse of the use of both sides of the paper (front and 
back), and also $12,5 \%$ for printing on draft paper, one side of which has already been used.

\section{Therefore, the application of Green IT enables the following benefits:}

- Cost reduction;

- Reduction of energy consumption;

- Institutional figure;

- Economy and paper reuse;

- Input reduction;

- Reduction of electronic waste;

- Enables a longer life cycle of the equipment;

- Rational use of technological equipment.

In a context of Green IT applicability, it is noted that companies are aware of the importance of being at the forefront of attitudes that positively impact their audience. In other words, thinking green adds value to the brand image, and the social appeal is enormous. Therefore, the carrier, by serving a range of multinationals tends to require a responsibility to be a generator of sustainable development. In the questionnaire available to the public, it was possible to measure the level of knowledge that people have about the subject of Green IT. Responses from 93 people were possible. According to graph 4 it was verified whether the respondent would apply the Green IT practice within the company. Thus $78,5 \%$ answered yes that they would apply the green IT tool. And the others, 21,5\%, answered that they would not apply this practice in their company. This shows that the world of technology is beginning to adopt this practice, which tends, increasingly, to grow and gain demand and meet the needs of a more sustainable world. And with these actions, companies gain the indicators of economic advantages, and especially a better image before the IT community and society, moving their actions and strategy. As shown in graph 5, the survey on agreeing that technology has always played an undefined role with respect to sustainability $80.6 \%$ said yes and only $19.4 \%$ said no. It is pertinent to state that the acceptance of the practice of Green IT is well seen in the business environment, because it offers a great differential in the current situation of the planet, the concepts of economic development are increasingly linked to sustainability. As in most activities and industries, Information Technology also has a significant impact on the environment.

In view of graph 6 , we can observe that most of the interviewees, that is, $87,1 \%$ agree that this set of practices adopted by the IT sector in a company can help support strategies that come to preserve the environment and reduce costs. And only $12,9 \%$ disagree with these practices. Since the Green IT practices bring as the main behavior change the economic factor, demonstrated by the large number of practices that provide an opportunity to increase revenues or reduce costs, whether they are energy, inputs, paper, water, transportation, maintenance or disposal. Even so, the benefits linked to institutional image, economy of physical space, respect for the environment, and even income generation, among others, make the adoption of these practices an important tool to implement environmentally correct actions (LUNARDI et al, 2014). Graph 7 questions the investment in ISO in a strategic way with the intention of profitability, benefits and improving the image of the company in international aspects. $83.9 \%$ answered yes that they would invest and only $16.1 \%$ answered no. Let's see why it is important to invest in ISO, since this tool brings world-class quality standards and can do business with the world, that is, internationally. And this achievement provides a number of advantages, such as:

- To increase productivity;

- Reduce spending;

- Engage employees;

- Improve communication with all segments of the target audience;

- Standardize work routines;

- Reduce risks due to poor service delivery;

- Improve the relationship with investors, clients and suppliers.

Therefore, these aspects go through definitions of how to make and immediate application in the day to day of the organization, requiring a systematic monitoring and record of how the work is being done in each phase, in a linear manner for benefits to the progress of the company.

\section{Conclusion}

Therefore, the new perspective of Green IT applied to the carrier, resulted in $21 \%$ energy savings to the company. While the reuse of paper, it reduces $50 \%$ of total paper consumption for printing documents and various reports. However, even if there is greater visibility regarding the concern for the environment, companies stop applying this IT management model, remaining in a consumerist culture. One of the actions still in progress is the disposal of electronic waste accumulated in the company, as some equipment may be moved to exclusive sectors and/or discarded or donated to needy institutions. The results collected at the end of June will be sent to a certifying body, along with proposals to raise awareness of the company, so that the services provided and products get the Green Seal and thus obtain the ISO 14001. So, it is noticeable that with the implementation of Green IT practices, it is possible to achieve savings and at the same time contribute to the environment, even if they are implemented in a small company. If the implementation is long-term, the chance of benefits will be even greater and noticeable to the corporation and society.

\section{Acknowledgements}

We thank God for given us health e forces. To our parents, out of love, encouragement e unconditional support. The Metropolitan Faculty of Manaus - FAMETRO and its entire team of professionals that gave a window today we glimpse a higher horizon, for waved confidence on merit e in ethics. To all teachers have given us knowledge. To all that direct or indirectly took part of our formation, thank you very much.

\section{REFERENCES}

Albertin, Alberto Luiz; Albertin, Rosa Maria de Moura 2012. Dimensões da utilização das tecnologias de informação: uma ferramenta de diagnóstico e análise. Revista Administração Pública, Rio de Janeiro, v. 46, n. 1, p. $125-$ 151, Feb. Available at: <http:/www.scielo.br/ scielo. php?script=sci_arttext\&pid=S0034-76122012000 100 007\&lng=en\&n̄rm=iso >. Access on: January 18, 2020.

BSI América 2011. ISO 14001 Environment. Available at: $<\mathrm{http}$ ://www.bsiamerica.com/en-us/Assessmentand- 
Certification-services/Management-systems/Standardsand-schemes/ISO-14001/>. Access on: Feb 19, 2020.

Genesis Computers 2019. Green IT: Sustainability in Information Technology. Available at: $<$ https://genesiscomputadores.com.br/2019/11/ti-verde/>. Access on: January 15, 2020.

Google 2020. Google Forms. Available at: https://www.google.com/forms/about/. Access on: March $15,2020$.

Lunardi, Guilherme Lerch, Simões, Renata, \& Frio, Ricardo Saraiva. 2014. TI Verde: umaanálise dos principais benefícios e prática sutilizadaspelasorganizações. REAd. RevistaEletrônica de Administração (Porto Alegre), 20(1), 1-30. https://doi.org/10.1590/S141323112014000100001.

Pinto, T. M. C.; Savoine, M. M 2011. Estudosobre TI Verde e suaaplicabilidadeem Araguaína. Revista do Instituto Tocantinense Presidente Antônio Carlos (ITPAC) Tocantins. Available at: http:/www.itpac.br/ arquivos/ Revista/42/3.pdf. Access on: January 15, 2020.
Souza, Márcio Antônio dos Santos 2013. Avaliação da utilização de práticas de tecnologias de informaçãoverdes no Instituto Federal do Amazonas. Manaus: UFAM.

Superintendência da Zona Franca de Manaus 2017. Polo Industrial de Manaus. SUFRAMA.. Available at: $<$ http://site.suframa.gov.br/assuntos/polo-industrial-demanaus>. Access on: January 15, 2020.

United Nations 2018. E-waste represents 'increasing risk' to the environment and human health, says a UN report. Available at: < https://news.un.org/en/story/2017/12/ 639312-electronic-waste-poses-growing-risk-

environment-human-health-un-report-warns>. Access on: 17 January 2020.

Westcon 2020. Sustainability: How important is it to invest in Green IT? Westcon Brazil. Available at: $<$ https://blogbrasil.westcon.com/sustentabilidade-qual-aimportancia-de-investir-em-uma-ti-verde $>$. Access on: January 15, 2020. 